\title{
Dokładność wyznaczania współczynnika ściśliwości gazu z podwyższoną zawartością wodoru - porównanie metod obliczeniowych
}

\begin{abstract}
W artykule przedstawiono porównanie różnych metod wyznaczania współczynnika ściśliwości gazu przy zwiększonej zawartości wodoru. Jako kontrolną zastosowano metodę GERG-2008. Badanymi metodami były: AGA8 i SGERG 88.
\end{abstract}

Słowa kluczowe: gaz ziemny, gaz koksowniczy, wodór, współczynnik ściśliwości gazu, równania AGA8, SGERG 88, GERG-2008.

\section{The accuracy of determining the compressibility factor for gas with increased hydrogen content - comparison of the calculation methods}

\begin{abstract}
The article presents a comparison of different methods of determining the gas compressibility factor for gas with enhanced hydrogen content. As the control method was used GERG-2008. The AGA8 and the SGERG 88 were the tested methods.
\end{abstract}

Key words: natural gas, coke gas, hydrogen, compressibility factors of gas, AGA8, SGERG 88, GERG-2008 equation.

\section{Wstęp}

Zgodnie z rozporządzeniem Ministra Gospodarki z dnia 27 grudnia 2007 r. [11] gazomierze i przeliczniki, które są używane do rozliczeń gazu, podlegają prawnej kontroli metrologicznej. Ze względu na przepisy zawarte w rozporządzeniu Ministra Gospodarki z dnia 28 grudnia 2007 r. [12] w polskim systemie rozliczeniowym gazu funkcjonują dwie wiodące metody obliczania współczynnika ściśliwości gazu. Pierwsza zgodnie z PN-EN ISO 12213-2 - obliczenia z zastosowaniem składu molowego (równanie AGA8-92DC) [9], druga zgodnie z PN-EN ISO 12213-3 - obliczenia z wykorzystaniem właściwości fizycznych (równanie SGERG-88) [10]. Obie określają szczegółowo dopuszczalne udziały molowe poszczególnych składników gazu. Obecnie z uwagi na problem ochrony środowiska, jak również działania związane z dywersyfikacją źródeł energii, coraz częściej mamy do czynienia z mieszaninami gazowymi, w których zawartość poszczególnych składników wykracza poza granice zdefinio- wane w ww. normach. Doskonałym przykładem jest tutaj gaz koksowniczy, w którym znaczną część mieszaniny stanowi wodór (na podstawie badań INiG - PIB: od 34,17\% mol $/ \mathrm{mol}$ do $60,34 \% \mathrm{~mol} / \mathrm{mol}$ ) [2], podczas gdy wyżej wymienione normy dopuszczają maksymalny udział molowy wodoru na poziomie $10 \%$. Z gazami z podwyższoną zawartością wodoru mamy do czynienia również w przypadku źródeł energii odnawialnych takich jak gaz syntezowy, powstający w procesie molekularnego recyklingu odpadów [4], czy w przypadku zagospodarowania nadwyżek energii pochodzących z elektrowni wiatrowych poprzez dodawanie wodoru do sieci gazociągowych [1]. Niniejsza praca skupia się właśnie na mieszaninach gazowych z różną zawartością wodoru. Dokonano analizy poprawności działania obu wspomnianych powyżej metod poza ich dopuszczalnymi granicami na tle metody kontrolnej GERG-2008 [8], która dopuszcza udział molowy wodoru do $40 \%$. Porównania przeprowadzono 
w granicach warunków gazociągowych, tj. temperatur od $-24^{\circ} \mathrm{C}$ do $65^{\circ} \mathrm{C}$ i ciśnień od 0 bar do 120 bar. Wykonano obliczenia dla kilku próbek gazu ze stopniowo zwiększaną zawartością wodoru.

\section{Współczynnik ściśliwości gazu - metody obliczania}

Do pomiaru objętości gazu stosuje się takie prawa i zależności jak równanie stanu Clapeyrona, prawo Avogadra czy stałość ciepła właściwego. Zależności te dotyczą tzw. gazu doskonałego, który jest pojęciem hipotetycznym. W przyrodzie mamy jednak do czynienia z gazami rzeczywistymi, dla których wymienione wyżej prawa mają zastosowanie tylko przy niskich ciśnieniach oraz niezbyt wysokich temperaturach. W gazociągach, gdzie gaz często transportowany jest pod wysokim ciśnieniem i w zmiennej temperaturze, należy dodatkowo uwzględnić odstępstwa od praw gazu doskonałego. Miarą tych odstępstw jest tzw. współczynnik ściśliwości gazu $Z$, do którego wyznaczenia stosuje się specjalne metody obliczeniowe. Bezwymiarowy współczynnik ściśliwości gazu $Z$ ma charakter najprostszego równania stanu gazu rzeczywistego. Współczynnik $Z$ jest stosunkiem objętości molowej gazu rzeczywistego do objętości molowej gazu doskonałego w tych samych warunkach ciśnienia i temperatury. Obecnie w przemyśle gazowniczym do obliczania współczynnika ściśliwości obowiązują porównywalne ze sobą dwie metody ISO: metoda SGERG-88 [9], oparta na wirialnym równaniu stanu i właściwościach fizycznych oraz metoda AGA8-92DC [10], oparta na równaniu typu wirialnego i składzie gazu. Dla podanego w obu normach podstawowego zakresu składu wartości współczynników ściśliwości są obliczane z dokładnością do $0,1 \%$, z wykluczeniem obszarów w pobliżu równowagi dwufazowej gaz-ciecz. W odniesieniu do udziału procentowego wodoru obie z powyższych metod charakteryzują się maksymalnym dopuszczalnym zakresem nieprzekraczającym $10 \%$ objętości molowej całej mieszaniny. Metodą, która dopuszcza większy udział molowy (do 40\%), jest GERG-2008 [8].

\section{Metoda AGA8-92DC}

W metodzie AGA8-92DC [9] wykorzystuje się równanie oparte na założeniu, że gaz ziemny o jakości gazociągowej może być, w celu obliczenia jego właściwości objętościowych, jednoznacznie scharakteryzowany za pomocą analizy składu. Analiza ta, a także ciśnienie i temperatura są stosowane jako dane wejściowe metody. W metodzie wykorzystuje się szczegółową analizę składu molowego, w której zaleca się uwzględnić wszystkie składniki, dla których wartość ułamka molowego przekracza 0,00005. Zwykle obejmuje to wszystkie węglowodory nasycone do $\mathrm{C}_{7}$ lub $\mathrm{C}_{8}$ oraz azot, dwutlenek węgla i hel. W przypadku innych gazów konieczne jest również wzięcie pod uwagę składników dodatkowych, takich jak para wodna, siarkowodór i eten. Współczynnik ściśliwości wyznaczany jest przy użyciu szczegółowego charakterystycznego równania AGA8 (określanego jako równanie AGA8-92DC), będącego rozszerzonym rów-

Tablica 1. Dopuszczalne zakresy wartości właściwości fizycznych gazu dla metody AGA8-92DC

\begin{tabular}{|l|c|c|}
\hline \multicolumn{1}{|c|}{ Parametr } & $\begin{array}{c}\text { Zakres } \\
\text { normalny }\end{array}$ & $\begin{array}{c}\text { Zakres } \\
\text { rozszerzony }\end{array}$ \\
\hline Ciśnienie bezwzględne $P$ & $0 \div 120 \mathrm{bar}$ & $0 \div 650 \mathrm{bar}$ \\
\hline Temperatura $t$ & $-10,15 \div 64,85^{\circ} \mathrm{C}$ & $-48,15 \div 76,85^{\circ} \mathrm{C}$ \\
\hline Ciepło spalania $H_{s}$ & $30 \div 45 \mathrm{MJ} / \mathrm{m}^{3}$ & $20 \div 48 \mathrm{MJ} / \mathrm{m}^{3}$ \\
\hline Gęstość względna $d$ & $0,55 \div 0,80$ & $0,55 \div 0,90$ \\
\hline
\end{tabular}

naniem typu wirialnego. Równanie to określono w raporcie AGA nr 8 [5]. Metodę tę stosuje się tylko do mieszanin jednofazowych w stanie gazowym (powyżej temperatury punktu rosy). Zmiennymi wejściowymi wymaganymi do stosowania

Tablica 2. Dopuszczalne wartości ułamków molowych składników gazu dla metody AGA8-92DC

\begin{tabular}{|l|c|c|}
\hline \multirow{2}{*}{\multicolumn{1}{|c|}{ Składnik }} & \multicolumn{2}{c|}{ Ułamek molowy } \\
\cline { 2 - 3 } & $\begin{array}{c}\text { zakres } \\
\text { normalny }\end{array}$ & $\begin{array}{c}\text { zakres } \\
\text { rozszerzony }\end{array}$ \\
\hline Metan $\mathrm{CH}_{4}$ & $0,7 \div 1,00$ & $0,5 \div 1,00$ \\
\hline Azot $\mathrm{N}_{2}$ & $0 \div 0,20$ & $0 \div 0,50$ \\
\hline Dwutlenek węgla $\mathrm{CO}_{2}$ & $0 \div 0,20$ & $0 \div 0,30$ \\
\hline Etan $\mathrm{C}_{2} \mathrm{H}_{6}$ & $0 \div 0,10$ & $0 \div 0,20$ \\
\hline Propan $\mathrm{C}_{3} \mathrm{H}_{8}$ & $0 \div 0,035$ & $0 \div 0,05$ \\
\hline Butany $\mathrm{C}_{4} \mathrm{H}_{10}$ & $0 \div 0,015$ & $0 \div 0,015$ \\
\hline Pentany $\mathrm{C}_{5} \mathrm{H}_{12}$ & $0 \div 0,005$ & $0 \div 0,005$ \\
\hline Heksany $\mathrm{C}_{6} \mathrm{H}_{14}$ & $0 \div 0,001$ & $0 \div 0,001$ \\
\hline Heptany $\mathrm{C}_{7} \mathrm{H}_{16}$ & $0 \div 0,0005$ & $0 \div 0,0005$ \\
\hline $\begin{array}{l}\text { Octany oraz wyższe } \\
\text { węglowodory } \mathrm{C}_{8+}\end{array}$ & $0 \div 0,0005$ & $0 \div 0,0005$ \\
\hline Wodór $\mathrm{H}_{2}$ & $0 \div 0,10$ & $0 \div 0,10$ \\
\hline Tlenek węgla CO & $0 \div 0,03$ & $0 \div 0,03$ \\
\hline Hel He & $0 \div 0,005$ & $0 \div 0,005$ \\
\hline Woda $\mathrm{H}_{2} \mathrm{O}$ & $0 \div 0,00015$ & $0 \div 0,00015$ \\
\hline
\end{tabular}


równania AGA8-92DC są ciśnienie bezwzględne, temperatura bezwzględna i skład molowy. Dopuszczalne zakresy parametrów gazu oraz dopuszczalne wartości udziałów molowych poszczególnych składników w gazie podane zostały w tablicach 1 i 2 . Niepewność wyników dla wszystkich ga- zów w granicach stężeń określonych przez zakres normalny (gaz ziemny o jakości gazociągowej) wynosi $\pm 0,1 \%$ natomiast dla zakresu rozszerzonego maksymalnie może wynosić $\pm 0,6 \%$. Szczegółowy rozkład niepewności dla zakresu rozszerzonego dostępny jest w pozycji [9].

\section{Metoda SGERG-88}

W metodzie SGERG-88 [10] stosuje się równanie oparte na założeniu, że gaz ziemny o jakości gazociągowej może być jednoznacznie scharakteryzowany przez odpowiedni i określony zestaw mierzalnych właściwości fizycznych, wykorzystywanych do obliczania jego właściwości objętościowych. W niniejszej metodzie właściwości te oraz ciśnienie i temperatura są stosowane jako dane wejściowe. Wykorzystuje się tu: ciepło spalania, gęstość względną oraz zawartość dwutlenku węgla. Metoda jest szczególnie użyteczna w typowej sytuacji, gdy nie jest znany cały skład molowy gazu, ale może być również preferowana ze względu na swoją prostotę. W przypadku gazów z dodatkami syntetycznymi powinna być znana zawartość wodoru. Metoda obliczania z wykorzystaniem właściwości fizycznych jest oparta na równaniu wirialnym GERG 88 (SGERG-88) w wersji standardowej dla gazów ziemnych. W metodzie tej traktuje się gaz ziemny jako mieszaninę pięciu składników, tj. równoważnego gazu węglowodorowego (gazu o właściwościach termodynamicznych identycznych z właściwościami mieszaniny węglowodorów zawartych w gazie ziemnym), azotu, dwutlenku węgla, wodoru i tlenku węgla. Do odpowiedniego scharakteryzowania właściwości termodynamicznych gazu węglowodorowego wymagane jest również jego molowe ciepło spalania.

Zmiennymi wejściowymi wymaganymi do zastosowania równania SGERG-88 są ciśnienie absolutne, temperatura bezwzględna, ciepło spalania odniesione do jednostki objętości, gęstość względna, ułamki molowe dwutlenku węgla i wodoru. Gęstość względna odnosi się do warunków normalnych $\left(101,325 \mathrm{kPa}\right.$ i $\left.0^{\circ} \mathrm{C}\right)$, a wartość ciepła spalania odnosi się do warunków normalnych $\left(101,325 \mathrm{kPa}\right.$ i $\left.0^{\circ} \mathrm{C}\right)$ i temperatury spalania $25^{\circ} \mathrm{C}$. Metoda ta znajduje zastosowanie jedynie dla mieszanin w fazie gazowej (powyżej punktu rosy). Dopuszczalne zakresy parametrów gazu oraz dopuszczalne wartości udziałów procentowych poszczególnych składników w gazie podane zostały w tablicach 3 i 4.

Niepewność wyznaczania współczynnika ściśliwości w zakresie temperatury od $-10,15^{\circ} \mathrm{C}$ do $64,85^{\circ} \mathrm{C}$ i przy ciśnieniach do 100 bar wynosi $\pm 0,1 \%$, natomiast $\pm 0,2 \%$ pomiędzy 100 bar i 120 bar dla gazów ziemnych, których ciepło spalania wynosi $30 \div 45 \mathrm{MJ} / \mathrm{m}^{3}$, gęstość względna mieści się w zakresie od 0,55 do 0,80 i które posiadają następujący skład:
Tablica 3. Dopuszczalne zakresy wartości właściwości fizycznych gazu dla metody SGERG-88

\begin{tabular}{|l|c|c|}
\hline \multicolumn{1}{|c|}{ Parametr } & $\begin{array}{c}\text { Zakres } \\
\text { normalny }\end{array}$ & $\begin{array}{c}\text { Zakres } \\
\text { rozszerzony }\end{array}$ \\
\hline Ciśnienie bezwzględne $P$ & $0 \div 100 \mathrm{bar}$ & $0 \div 120 \mathrm{bar}$ \\
\hline Temperatura $t$ & $-10,15 \div 64,85^{\circ} \mathrm{C}$ & $-10,15 \div 64,85^{\circ} \mathrm{C}$ \\
\hline Ciepło spalania $H_{s}$ & $30 \div 45 \mathrm{MJ} / \mathrm{m}^{3}$ & $20 \div 48 \mathrm{MJ} / \mathrm{m}^{3}$ \\
\hline Gęstość względna $d$ & $0,55 \div 0,80$ & $0,55 \div 0,90$ \\
\hline
\end{tabular}

Tablica 4. Dopuszczalne wartości ułamków molowych składników gazu dla metody SGERG-88

\begin{tabular}{|l|c|c|}
\hline \multirow{2}{*}{\multicolumn{1}{|c|}{ Składnik }} & \multicolumn{2}{c|}{ Ułamek molowy } \\
\cline { 2 - 3 } & $\begin{array}{c}\text { zakres } \\
\text { normalny }\end{array}$ & $\begin{array}{c}\text { zakres } \\
\text { rozszerzony }\end{array}$ \\
\hline Metan $\mathrm{CH}_{4}$ & $0,7 \div 1,00$ & $0,5 \div 1,00$ \\
\hline Azot $\mathrm{N}_{2}$ & $0 \div 0,20$ & $0 \div 0,50$ \\
\hline Dwutlenek węgla $\mathrm{CO}_{2}$ & $0 \div 0,20$ & $0 \div 0,20$ \\
\hline Etan $\mathrm{C}_{2} \mathrm{H}_{6}$ & $0 \div 0,10$ & $0 \div 0,20$ \\
\hline Propan $\mathrm{C}_{3} \mathrm{H}_{8}$ & $0 \div 0,035$ & $0 \div 0,05$ \\
\hline Butany $\mathrm{C}_{4} \mathrm{H}_{10}$ & $0 \div 0,015$ & $0 \div 0,015$ \\
\hline Pentany $\mathrm{C}_{5} \mathrm{H}_{12}$ & $0 \div 0,005$ & $0 \div 0,005$ \\
\hline Heksany $\mathrm{C}_{6} \mathrm{H}_{14}$ & $0 \div 0,001$ & $0 \div 0,001$ \\
\hline Heptany $\mathrm{C}_{7} \mathrm{H}_{16}$ & $0 \div 0,0005$ & $0 \div 0,0005$ \\
\hline $\begin{array}{l}\text { Octany oraz wyższe } \\
\text { węglowodory } \mathrm{C}_{8+}\end{array}$ & $0 \div 0,0005$ & $0 \div 0,0005$ \\
\hline Wodór $\mathrm{H}_{2}$ & $0 \div 0,10$ & $0 \div 0,10$ \\
\hline Tlenek węgla CO & $0 \div 0,03$ & $0 \div 0,03$ \\
\hline Hel He & $0 \div 0,005$ & $0 \div 0,005$ \\
\hline Woda $\mathrm{H}_{2} \mathrm{O}$ & $0 \div 0,00015$ & $0 \div 0,00015$ \\
\hline
\end{tabular}

$$
\begin{array}{ll}
\text { - } & x_{\mathrm{N} 2} \leq 0,20 ; \\
\text { - } & x_{\mathrm{CO} 2} \leq 0,09 ; \\
\text { - } & x_{\mathrm{C} 2 \mathrm{H} 6} \leq 0,10 ; \\
\text { - } & x_{\mathrm{H} 2} \leq 0,10 .
\end{array}
$$

W przypadku gazów zawierających $\mathrm{CO}_{2}$, dla których ułamek molowy dwutlenku węgla przewyższa 0,09 , niepewność $\pm 0,1 \%$ jest zachowana dla ciśnień do 60 bar i temperatur od $-10,15^{\circ} \mathrm{C}$ do $64,85^{\circ} \mathrm{C}$. Szczegółowy rozkład niepewności dla zakresu rozszerzonego, którego zakładana niepewność jest większa, zamieszczony został w pozycji [10]. 


\section{Metoda GERG-2008}

Metoda GERG-2008 [8] bazuje na tym, że gaz ziemny albo dowolny inny rodzaj mieszaniny gazowej może być w pełni charakteryzowany do obliczenia jego właściwości termodynamicznych poprzez analizę jego składu. Analiza wszystkich składników wraz z temperaturą i gęstością gazu są wystarczającymi danymi wejściowymi do obliczeń za pomocą tej metody. W praktyce jako zmienne wejściowe dostępne są temperatura i ciśnienie gazu, a zatem należy najpierw za pomocą podanych w metodzie równań iteracyjnie obliczyć gęstość. Mieszanina gazowa reprezentowana jest $\mathrm{w}$ tej metodzie przez 21 składników. Dopuszczalne zakresy parametrów gazu oraz dopuszczalne wartości ułamków molowych poszczególnych jego składników podane zostały w tablicach 5 i 6 . Niepewność wyznaczania współczynnika ściśliwości dla mieszanin jednofazowych w zakresie normalnym jest mniejsza lub równa $0,1 \%$, w zakresie rozszerzonym mieści się w przedziale $0,2 \div 0,5 \%$. Więcej o metodzie GERG-2008 można znaleźć w pozycji [3].

Tablica 5. Dopuszczalne zakresy wartości właściwości fizycznych gazu dla metody GERG-2008

\begin{tabular}{|l|c|c|}
\hline \multicolumn{1}{|c|}{ Parametr } & $\begin{array}{c}\text { Zakres } \\
\text { normalny }\end{array}$ & $\begin{array}{c}\text { Zakres } \\
\text { rozszerzony }\end{array}$ \\
\hline Ciśnienie absolutne $P$ & $0 \div 350$ bar & $0 \div 700$ bar \\
\hline Temperatura $t$ & $-183,1 \div 176,85^{\circ} \mathrm{C}$ & $-213,15 \div 426,85^{\circ} \mathrm{C}$ \\
\hline
\end{tabular}

Tablica 6. Dopuszczalne wartości ułamków molowych składników gazu dla metody GERG-2008

\begin{tabular}{|l|c|c|}
\hline \multirow{2}{*}{\multicolumn{1}{|c|}{ Składnik }} & \multicolumn{2}{c|}{ Ułamek molowy } \\
\cline { 2 - 3 } & $\begin{array}{c}\text { zakres } \\
\text { normalny }\end{array}$ & $\begin{array}{c}\text { zakres } \\
\text { rozszerzony }\end{array}$ \\
\hline Metan $\mathrm{CH}_{4}$ & $0,7 \div 1,00$ & $0,3 \div 1,00$ \\
\hline Azot $\mathrm{N}_{2}$ & $0 \div 0,20$ & $0 \div 0,55$ \\
\hline Dwutlenek węgla $\mathrm{CO}_{2}$ & $0 \div 0,20$ & $0 \div 0,30$ \\
\hline Etan $\mathrm{C}_{2} \mathrm{H}_{6}$ & $0 \div 0,10$ & $0 \div 0,25$ \\
\hline Propan $\mathrm{C}_{3} \mathrm{H}_{8}$ & $0 \div 0,035$ & $0 \div 0,14$ \\
\hline n-butan $+\mathrm{i}-$ butan $\mathrm{C}_{4} \mathrm{H}_{10}$ & $0 \div 0,015$ & $0 \div 0,06$ \\
\hline n-pentan $+\mathrm{i}-$ pentan $\mathrm{C}_{5} \mathrm{H}_{12}$ & $0 \div 0,005$ & $0 \div 0,005$ \\
\hline n-heksan $\mathrm{C}_{6} \mathrm{H}_{14}$ & $0 \div 0,001$ & $0 \div 0,002$ \\
\hline n-heptan $\mathrm{C}_{7} \mathrm{H}_{16}$ & $0 \div 0,0005$ & $0 \div 0,001$ \\
\hline Oktan + nonan + dekan $\mathrm{C}_{8+}$ & $0 \div 0,0005$ & $0 \div 0,0005$ \\
\hline Wodór $\mathrm{H}_{2}$ & $0 \div 0,10$ & $0 \div 0,40$ \\
\hline Tlen $\mathrm{O}_{2}$ & $0 \div 0,0002$ & $0 \div 0,02$ \\
\hline Tlenek węgla CO & $0 \div 0,03$ & $0 \div 0,13$ \\
\hline Woda $\mathrm{H}_{2} \mathrm{O}$ & $0 \div 0,00015$ & $0 \div 0,0002$ \\
\hline Siarkowodór $\mathrm{H}_{2} \mathrm{~S}$ & $0 \div 0,0002$ & $0 \div 0,27$ \\
\hline Hel He & $0 \div 0,005$ & $0 \div 0,005$ \\
\hline Argon Ar & $0 \div 0,0002$ & $0 \div 0,0005$ \\
\hline
\end{tabular}

\section{Oprogramowanie komputerowe}

Na potrzeby niniejszych badań opracowany został program, który umożliwił porównanie wyników obliczeń uzyskanych za pomocą metod AGA8 i SGERG- 88 z metodą kontrolną GERG-2008. Rysunek 1 przedstawia interfejs programu. Na podstawie wprowadzonych parametrów gazu, ciśnienia i temperatury oraz warunków odniesienia (bazowych) program oblicza współczynnik ściśliwości gazu za pomocą metody kontrolnej i badanej. Z uzyskanych wyników obliczany jest błąd procentowy $E_{C}$, będący miarą rozbieżności pomiędzy metodami.

$$
E_{C}=\left(Z_{\text {badany }} / Z_{\text {kontrolny }}-1\right) \cdot 100 \%
$$

gdzie:

$Z_{\text {kontrolny }}$ - współczynnik ściśliwości wyznaczony za pomocą metody kontrolnej,

$Z_{\text {badany }}$ - współczynnik ściśliwości wyznaczony za pomocą metody badanej.

Aby sprawdzenie poprawności obliczania według danej metody miało sens, porównanie takie należy wykonać w całym zakresie ciśnieniowym i temperaturowym badanej metody. Uzyskane w ten sposób wyniki przedstawiane są na wykresie, gdzie wartość błędu $\left|E_{C}\right|$ określana jest za pomocą kolorowej skali. Kolor ciemnozielony oznacza zerowy błąd pomiędzy metodami, żółty jest zarezerwowany dla błędów wynoszących około $0,2 \%$, czerwony dla $0,5 \%$, różowy $-0,7 \%$, a niebieska barwa to błąd w granicach $1 \%$. Wartości pośrednie błędów są na wykresach oznaczone za pomocą odcieni tych kolorów.

Najistotniejszą część oprogramowania stanowią podprogramy z algorytmami dla poszczególnych metod obliczeniowych. W przypadku metod AGA8-92DC i SGERG-88 wykorzystano podprogramy ze stanowiska pomiarowego do badania przeliczników objętości w Zakładzie Metrologii Przepływów w Instytucie Nafty i Gazu - PIB w Krakowie. Instytut jest jednostką notyfikowaną o numerze identyfikacyjnym 1450. W ramach dyrektywy MID INiG - PiB posiada notyfikację w odniesieniu do gazomierzy i przeliczników w zakresie modułów: B (badanie typu) oraz D (zapewnienie jakości produkcji) [6]. Jako podprogram dla metody GERG-2008 zastosowano oprogramowanie autorstwa prof. dr. inż. Wolfganga Wagnera z Ruhr-Universität w Bochum w Niemczech [7]. 


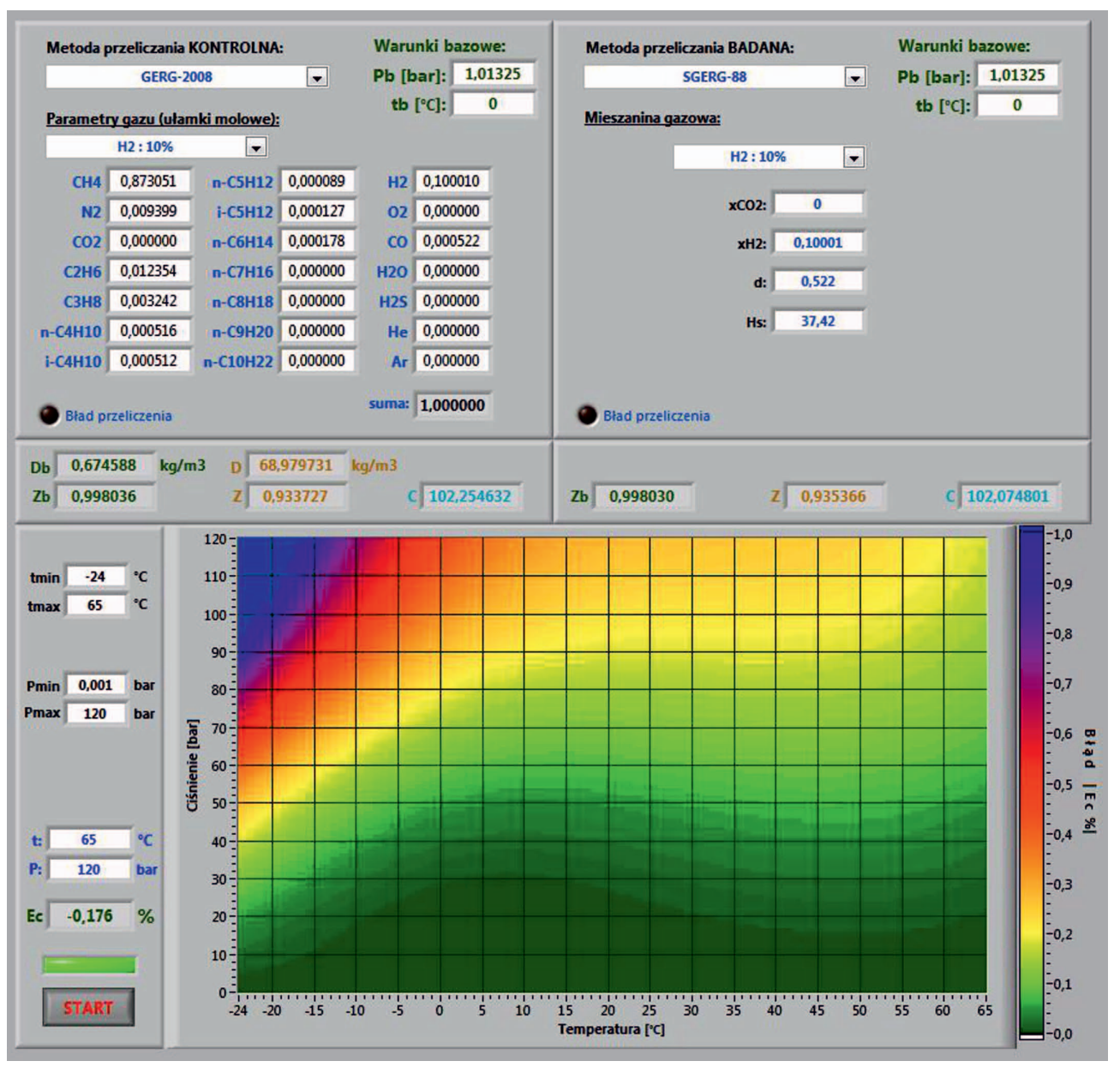

Rys. 1. Interfejs programu komputerowego

\section{Badania}

Celem badań było sprawdzenie poprawności działania metod obliczeniowych AGA8-92DC i SGERG-88 dla próbek gazu, w których zawartość wodoru znacznie przekracza dopuszczalne granice określone w tych metodach. Obie metody zezwalają na maksymalny udział molowy wodoru na poziomie $10 \%$. Badanie miało pozwolić na określenie, w jakich granicach ciśnień, temperatur i składów gazu stosowanie tych dwóch metod jest jeszcze możliwe, a otrzymywane wartości błędów akceptowalne.

Aby badanie mogło być wykonane poprawnie, należało porównać wyniki otrzymane $\mathrm{z}$ ww. metod z metodą kontrolną, która zezwala na większy udział wodoru. Taką metodą jest GERG-2008, która w rozszerzonym zakresie dopuszcza $40 \%$ udziału molowego wodoru w składzie gazu.

Badania przeprowadzono na wygenerowanych komputerowo próbkach gazu ze stopniowo zwiększaną zawartością wodoru w przedziale $0 \div 40 \% \mathrm{~mol} / \mathrm{mol}$ (tablica 7 ). Próbki generowane były poprzez mieszanie czystego wodoru z typowym gazem wysokometanowym tak, by liczba Wobbego i ciepło spalania otrzymanego gazu były zgodne z przyjętymi w Polsce standardami.
Obserwacje prowadzono dla zakresu temperatur $-24 \div 65^{\circ} \mathrm{C}$ i ciśnień $0 \div 120$ bar. Jako warunki odniesienia przyjęto $P=101,325 \mathrm{kPa}$ i $t=0^{\circ} \mathrm{C}$. Wynik obliczeń dla każdej próbki został przedstawiony na osobnym wykresie. Jako kryterium poprawności wyznaczania współczynnika $Z$ przyjęto wartość błędu $\left|E_{C}\right|$, która powinna być mniejsza lub równa $0,1 \%$.

Dla metody AGA8-92DC uzyskano zaskakująco dobre rezultaty. W całym porównywanym zakresie maksymalny błąd $\left|E_{C}\right|$ metody nie przekroczył $0,2 \%$, a w zdecydowanej większości przypadków mieścił się poniżej $0,05 \%$ (rysunki od 2 do 6 ).

Metoda SGERG-88 w porównaniu z poprzednią metodą wypadła dużo gorzej. Tutaj błąd $\left|E_{C}\right|$ w skrajnych przypadkach znacznie przekroczył $0,5 \%$, mimo to, jak wynika z wykresów, można wyznaczyć węższe zakresy dla niższych wartości ciśnień, w których stosowanie tej metody nadal ma sens (rysunki od 7 do 11). Należy zauważyć, że błąd $\left|E_{C}\right|$ na wykresach przyjmuje najwyższe wartości poniżej temperatury $-10,15^{\circ} \mathrm{C}$, czyli poza zakresem normalnym i rozszerzonym stosowania metody SGERG-88. Również tendencja zmian błędu $\left|E_{C}\right|$ we wspomnianych punktach w stosunku 


\section{NAFTA-GAZ}

do zawartości wodoru w próbce gazu nie jest jednoznaczna. w próbce stanowi przyczynę pogorszenia się wyników meDlatego nie można uznać, że to wzrost zawartości wodoru tody SGERG-88.

Tablica 7. Składy poszczególnych próbek gazu z podwyższoną zawartością wodoru

\begin{tabular}{|c|c|c|c|c|c|c|c|c|c|c|c|c|c|}
\hline \multirow{2}{*}{$\begin{array}{c}\text { Nazwa } \\
\text { gazu }\end{array}$} & $\begin{array}{c}\text { metan } \\
\mathrm{CH}_{4}\end{array}$ & $\begin{array}{c}\text { etan } \\
\mathrm{C}_{2} \mathrm{H}_{6}\end{array}$ & $\begin{array}{c}\text { propan } \\
\mathrm{C}_{3} \mathrm{H}_{8}\end{array}$ & $\begin{array}{c}\text { n-butan } \\
\mathrm{n}-\mathrm{C}_{4} \mathrm{H}_{10}\end{array}$ & $\begin{array}{c}\text { i-butan } \\
\mathrm{i}-\mathrm{C}_{4} \mathrm{H}_{10}\end{array}$ & $\begin{array}{c}\text { n-pentan } \\
\mathrm{n}-\mathrm{C}_{5} \mathrm{H}_{12}\end{array}$ & $\begin{array}{c}\text { i-pentan } \\
\mathrm{i}-\mathrm{C}_{5} \mathrm{H}_{12}\end{array}$ & $\begin{array}{c}\text { heksan } \\
\mathrm{C}_{6} \mathrm{H}_{14}\end{array}$ & $\begin{array}{c}\text { azot } \\
\mathrm{N}_{2}\end{array}$ & $\begin{array}{c}\text { tlenek } \\
\text { węgla } \\
\mathrm{CO}\end{array}$ & $\begin{array}{c}\text { wodór } \\
\mathrm{H}_{2}\end{array}$ & $\begin{array}{c}\text { Ciepło } \\
\text { spalania } \\
{\left[\mathrm{MJ} / \mathrm{m}^{3}\right]}\end{array}$ & $\begin{array}{c}\text { Gęstość } \\
\text { względna } \\
{[-]}\end{array}$ \\
\hline $0,5 \% \mathrm{H}_{2}$ & 96,5218 & 1,3658 & 0,3584 & 0,0570 & 0,0566 & 0,0099 & 0,0140 & 0,0197 & 1,0391 & 0,0577 & 0,5000 & 40,04 & 0,570 \\
\hline $10 \% \mathrm{H}_{2}$ & 87,3051 & 1,2354 & 0,3242 & 0,0516 & 0,0512 & 0,0089 & 0,0127 & 0,0178 & 0,9399 & 0,0522 & 10,0010 & 37,42 & 0,522 \\
\hline $20 \% \mathrm{H}_{2}$ & 77,5979 & 1,0980 & 0,2881 & 0,0458 & 0,0455 & 0,0079 & 0,0113 & 0,0158 & 0,8353 & 0,0464 & 20,0080 & 34,67 & 0,471 \\
\hline $30 \% \mathrm{H}_{2}$ & 67,9367 & 0,9613 & 0,2523 & 0,0401 & 0,0398 & 0,0069 & 0,0099 & 0,0139 & 0,7314 & 0,0406 & 29,9671 & 31,93 & 0,421 \\
\hline $40 \% \mathrm{H}_{2}$ & 58,1414 & 0,8227 & 0,2159 & 0,0344 & 0,0341 & 0,0059 & 0,0084 & 0,0119 & 0,6259 & 0,0348 & 40,0646 & 29,16 & 0,370 \\
\hline
\end{tabular}

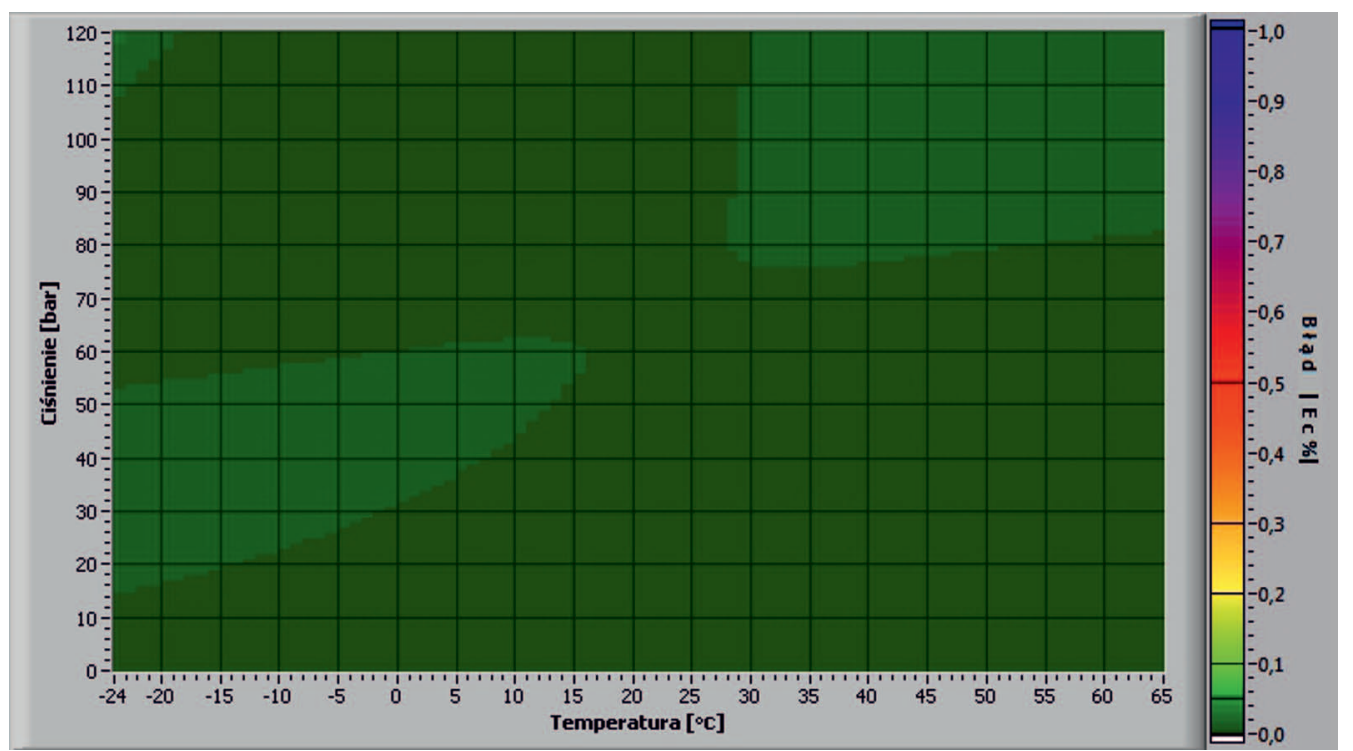

Rys. 2. Metoda kontrolna GERG-2008, metoda badana AGA8-DC92, gaz 0,5\% $\mathrm{H}_{2}$

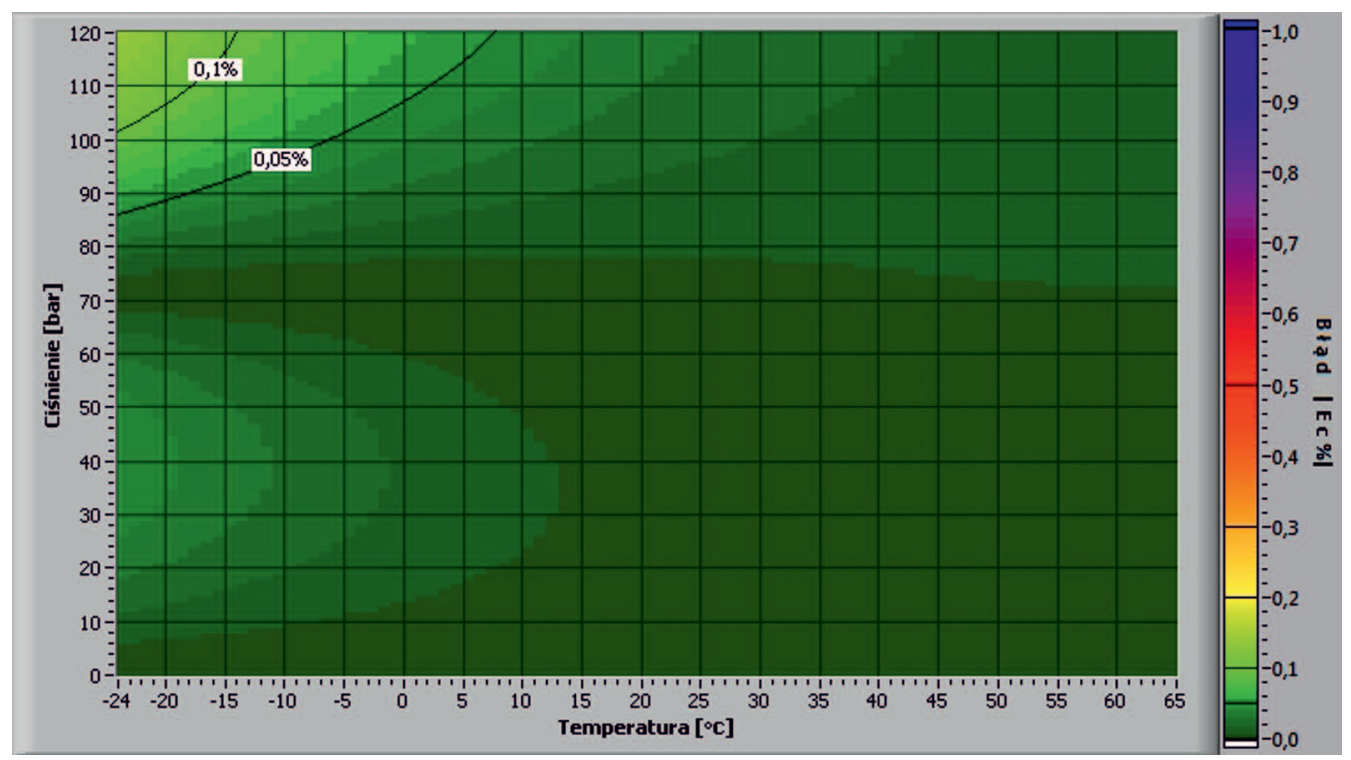

Rys. 3. Metoda kontrolna GERG-2008, metoda badana AGA8-DC92, gaz 10\% $\mathrm{H}_{2}$ 


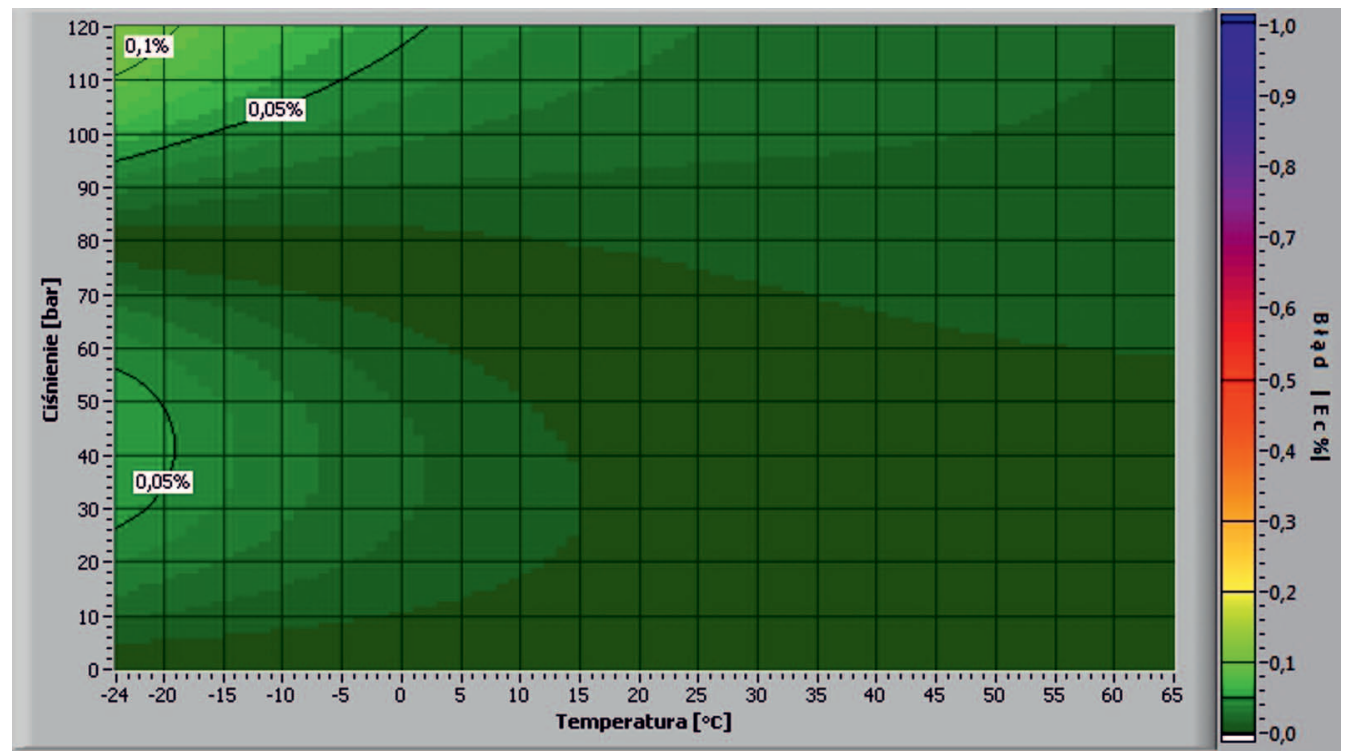

Rys. 4. Metoda kontrolna GERG-2008, metoda badana AGA8-DC92, gaz 20\% $\mathrm{H}_{2}$

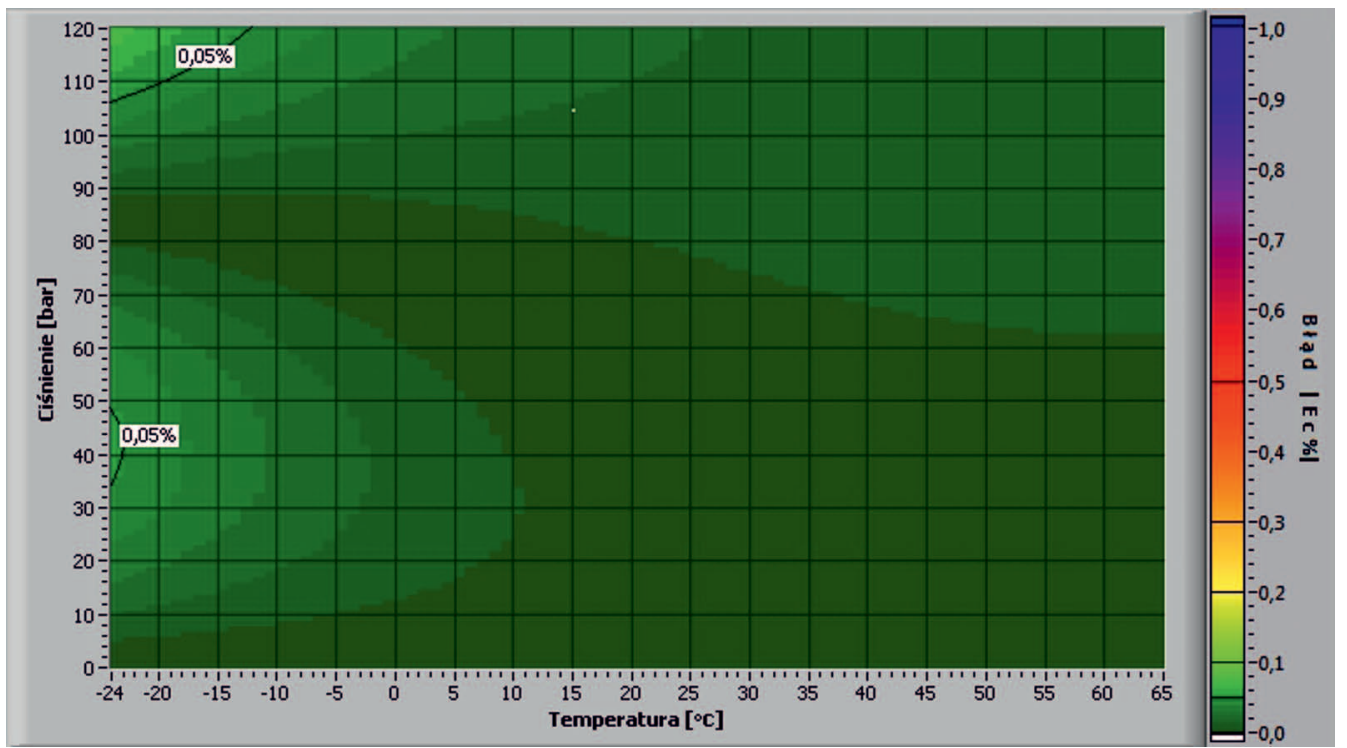

Rys. 5. Metoda kontrolna GERG-2008, metoda badana AGA8-DC92, gaz 30\% $\mathrm{H}_{2}$

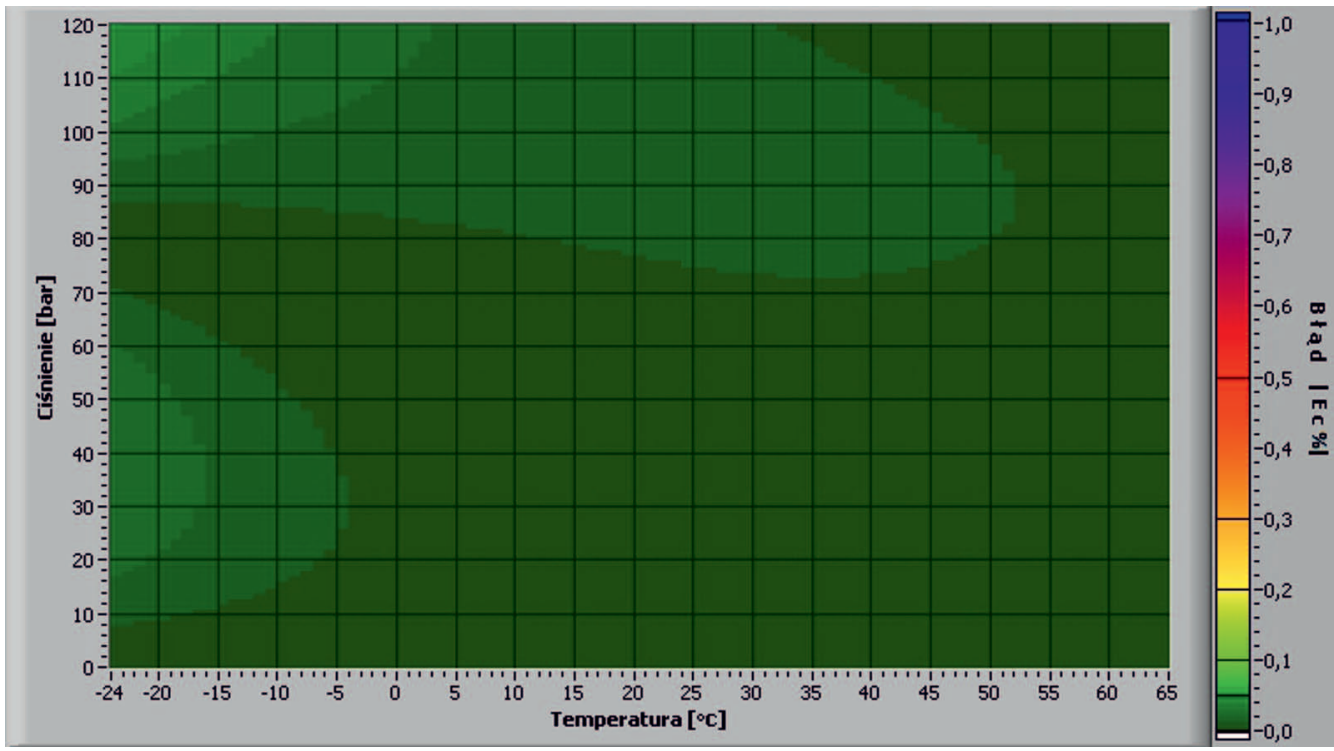

Rys. 6. Metoda kontrolna GERG-2008, metoda badana AGA8-DC92, gaz 40\% $\mathrm{H}_{2}$ 


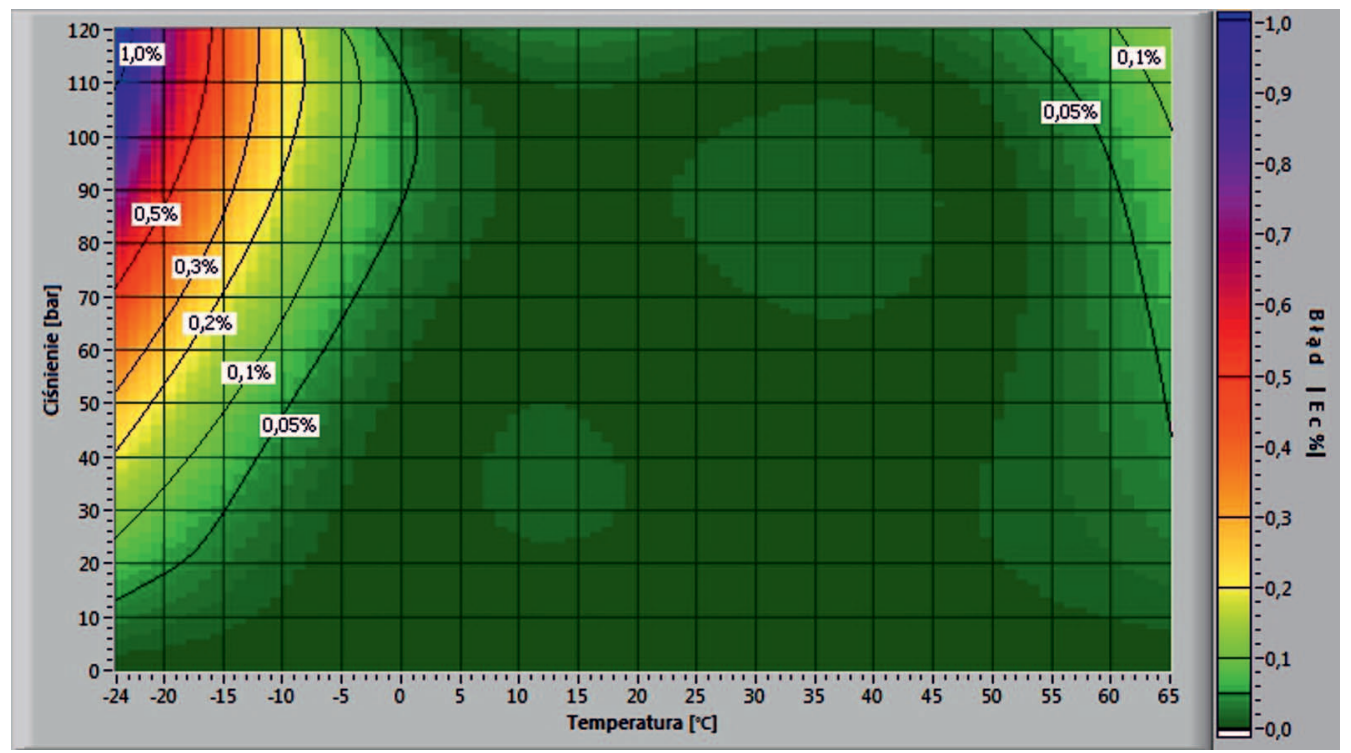

Rys. 7. Metoda kontrolna GERG-2008, metoda badana SGERG-88, gaz 0,5\% $\mathrm{H}_{2}$

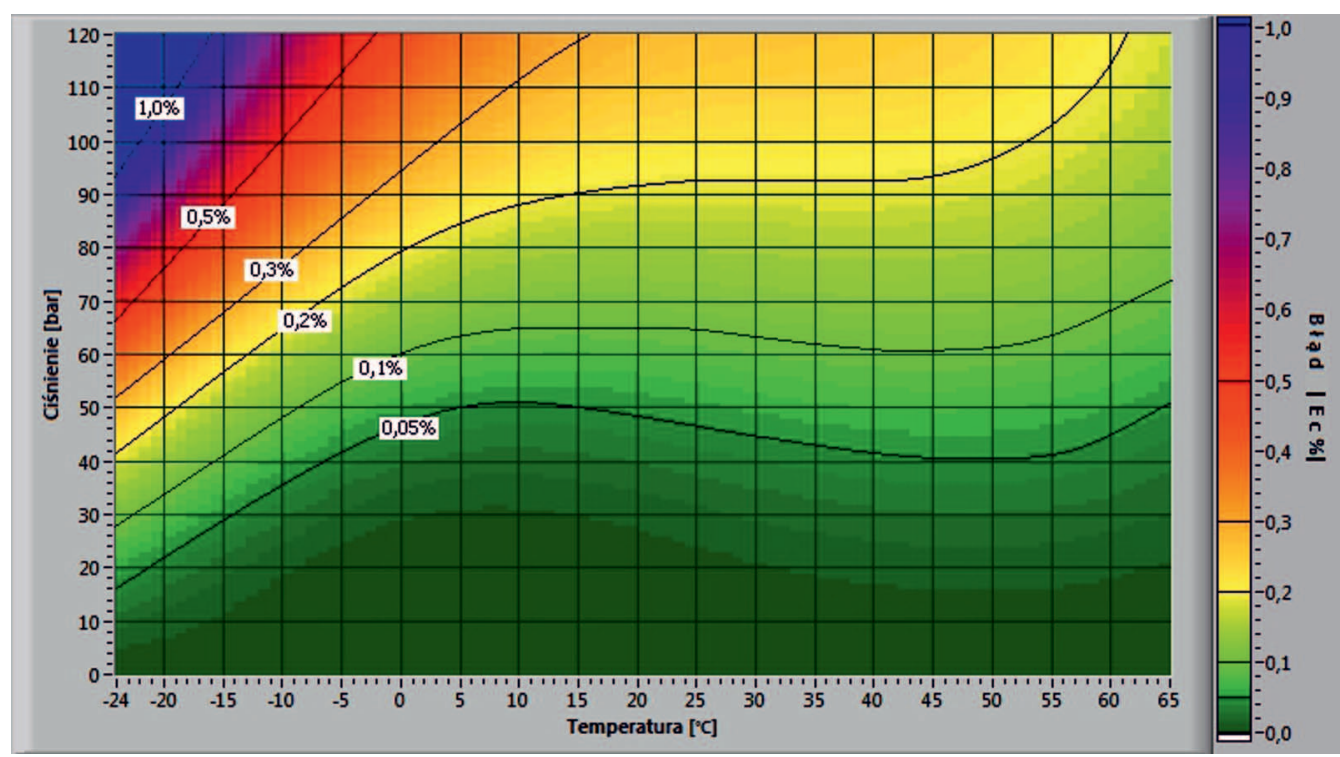

Rys. 8. Metoda kontrolna GERG-2008, metoda badana SGERG-88, gaz 10\% $\mathrm{H}_{2}$

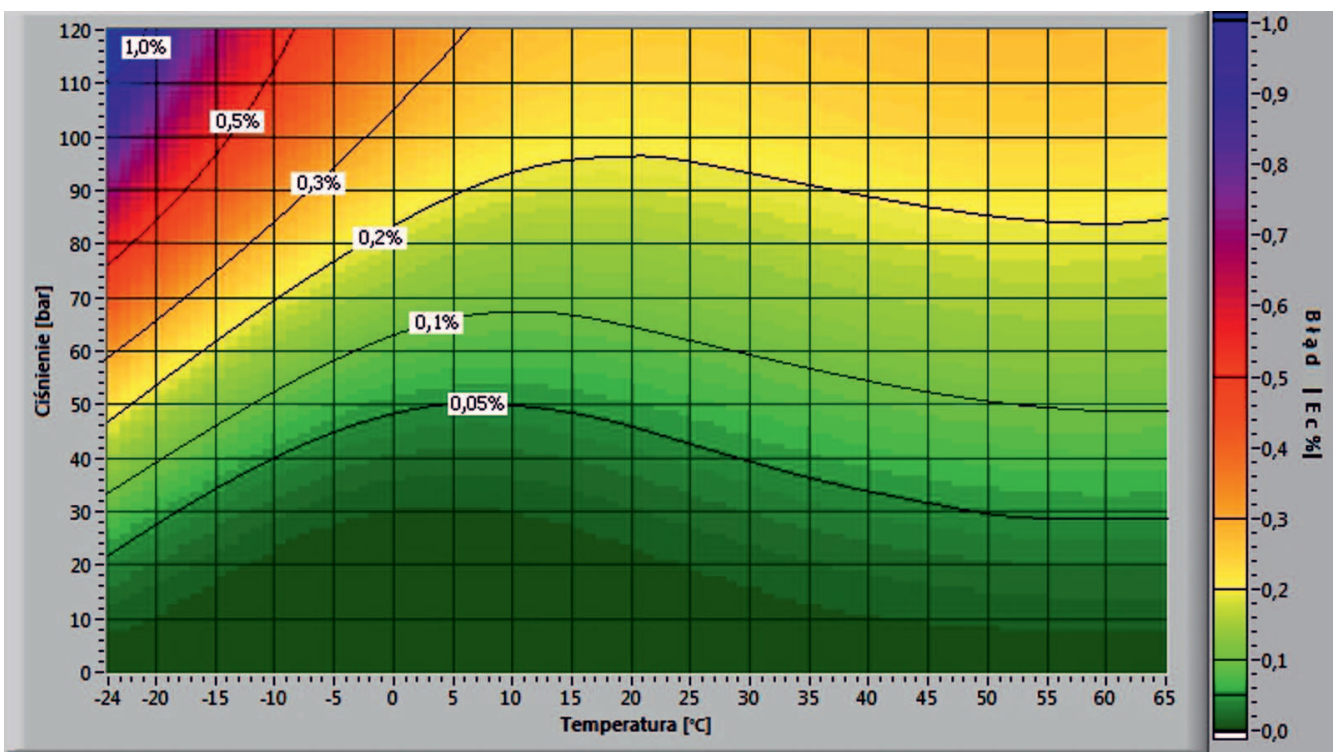

Rys. 9. Metoda kontrolna GERG-2008, metoda badana SGERG-88, gaz 20\% $\mathrm{H}_{2}$ 


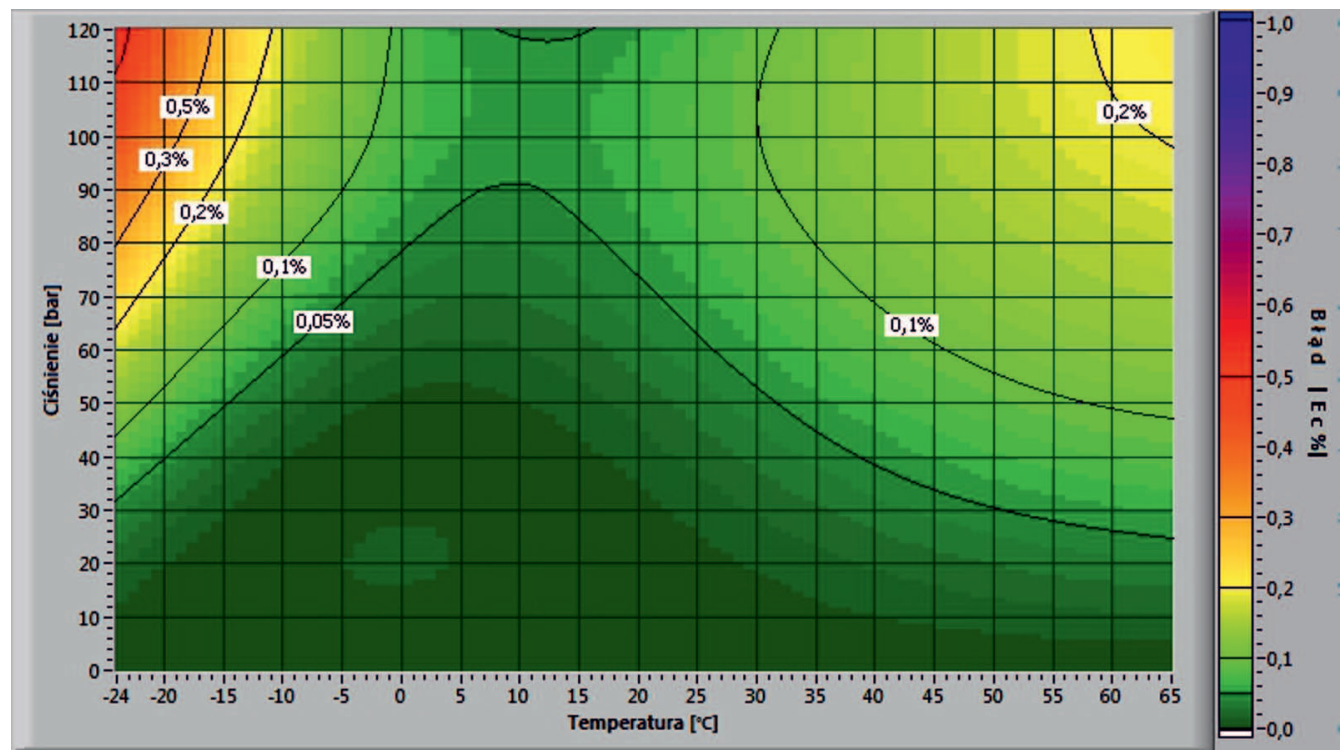

Rys. 10. Metoda kontrolna GERG-2008, metoda badana SGERG-88, gaz 30\% $\mathrm{H}_{2}$

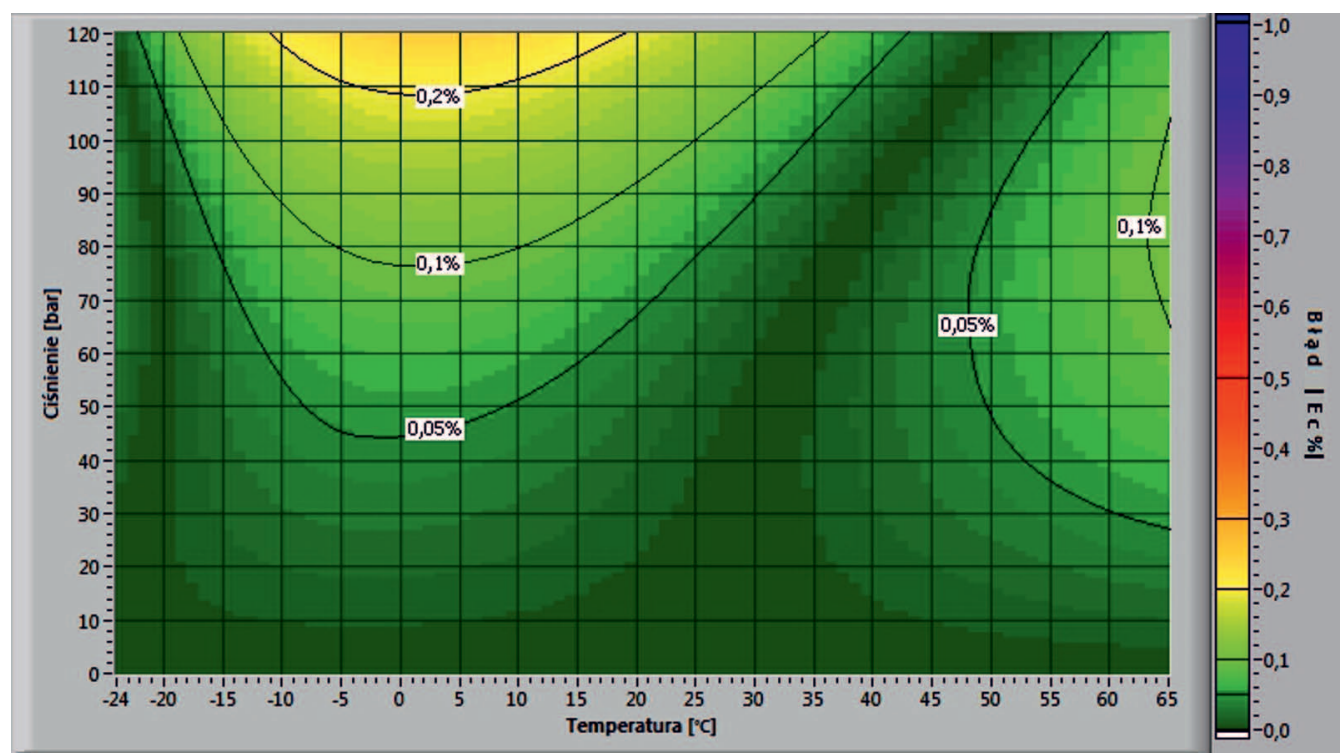

Rys. 11. Metoda kontrolna GERG-2008, metoda badana SGERG-88, gaz 40\% $\mathrm{H}_{2}$

\section{Podsumowanie i wnioski}

Autorzy opracowujący poszczególne metody obliczeniowe tak dobierają granice ciśnienia, temperatury i składu gazu, aby wykonywane obliczenia współczynnika ściśliwości $Z$ były poprawne dla każdego możliwego przypadku. Jak wykazały przeprowadzone symulacje, w niektórych sytuacjach znacznie wykraczających poza zalecane granice metody ta nadal zachowuje się prawidłowo, dając poprawny wynik obliczeń. W związku z tym, gdy dla metody, która aktualnie jest stosowana $\mathrm{w}$ przeliczniku, zalecana zawartość wodoru zostanie przekroczona, nie musi się to wiązać od razu z koniecznością zmiany metody lub wymiany całego przelicznika. Wykorzystując porównania podobne do zastosowanych w niniejszym artykule, można stwierdzić, czy aktualna metoda sobie $\mathrm{z}$ tym zadaniem odpowiednio poradzi.
Doskonałym przykładem jest tu metoda AGA8-92DC, w której zalecany udział molowy wodoru wynosi $10 \% \mathrm{~mol} / \mathrm{mol}$ objętości całego gazu. Okazuje się jednak, że metoda daje zadowalające rezultaty, gdy zawartość tego składnika wzrośnie nawet do $40 \% \mathrm{~mol} / \mathrm{mol}$ objętości gazu. Podejście takie należałoby stosować jednak niezwykle rozważnie, zawsze mając pewność, że warunki pomiaru i skład gazu nie ulegną zmianie. Należy również pamiętać, że swoboda w zakresie doboru metody istnieje tylko wtedy, gdy nie mamy do czynienia z systemem rozliczeniowym, w którym to odpowiednie dokumenty określają dostępne metody obliczeniowe, lub z przelicznikami podlegającymi jurysdykcji ustawy Prawo o miarach, tj. posiadającymi zatwierdzenie typu i legalizację pierwotną [6]. 
Analizując przeprowadzone obserwacje, warto jeszcze zwrócić uwage na nieliniowość działania badanych metod obliczeniowych. W większości przypadków linie na wykresach są pofalowane, a często również wzrosty błędów wy- stępują punktowo. Wykonując więc tego typu analizy należy stosować możliwie jak najmniejsze kroki próbkowania. Najlepiej tak jak w przypadku zamieszczonych obserwacji nie rzadziej niż co $1^{\circ} \mathrm{C}$ i co 1 bar.

Prosimy cytować jako Nafta-Gaz 2016, nr 5, s. 329-338, DOI: 10.18668/NG.2016.05.04

Artykuł nadesłano do Redakcji 9.12.2015 r. Zatwierdzono do druku 10.02.2016 r.

Artykuł powstał na podstawie pracy statutowej pt. Zastosowanie istniejacych uktadów pomiarowych oraz algorytmów obliczeniowych do pomiarów objętości wodoru - praca INiG - PIB na zlecenie MNiSW; nr zlecenia: 46/GM/15, nr archiwalny: DK-4100-46/15.

\section{Literatura}

[1] Chaczykowski M., Osiadacz A. J.: Zarządzanie systemem gazowniczym w warunkach zróżnicowanej jakości gazu. Przegląd Gazowniczy 2015, vol. 47, nr 3, s. 12-17.

[2] Holewa-Rataj J., Szlęk M.: Wpływ poprawności wyznaczenia wspólczynnika ściśliwości na poprawność obliczeń ciepła spalania gazu dla gazów o składzie innym niż przewidziany norma PN-EN ISO 6976:2008. Nafta-Gaz 2015, nr 7 , s. 481-486.

[3] Kunz O., Wagner W.: The GERG-2008 Wide-Range Equation of State for Natural Gases and Other Mixtures: An Expansion of GERG-2004. Journal of Chemical \& Engineering Data 2012, vol. 57, no. 11, s. 3032-3091. DOI: 10.1021/je300655b.

[4] Pilawski M., Flisiewicz B., Pucek J.: Gaz syntezowy z odpadów jako źródło czystej energii. Energetyka 2012, nr 5, s. 244-245.

[5] Starling K. E., Savidge J. L.: Compressibility Factors of Natural Gas and Other Related Hydrocarbon Gases. Cata$\log$ No. XQ9212. American Gas Association (AGA) Transmission Measurement Committee Report No. 8, American Petroleum Institute (API) MPMS, chapter 14.2, second edition, November 1992.

[6] Tyszownicka M., Jaworski J.: Wybrane problemy systemu oceny zgodności i prawnej kontroli metrologicznej na przykładzie gazomierzy i przeliczników. Nafta-Gaz 2012, nr 12, s. $1030-1035$.

[7] Wagner W.: Description of the Gas Version of the Software Package for the Calculation of Thermodynamic Properties from the GERG-2008 Wide-Range Equation of State for Natural Gases and Other Mixtures. Lehrstuhl für Thermodynamik Fakultät für Maschinenbau 2012.

\section{Akty prawne i normatywne}

[8] ISO 20765-2:2015 Natural gas - Calculation thermodynamic properties. Part 2: Single-phase properties (gas, liquid, and dense fluid) for extended ranges of application.

[9] PN-EN ISO 12213-2:2010 Gaz ziemny. Obliczanie wspótczynnika ściśliwości. Część 2: Obliczenia z zastosowaniem sktadu molowego.

[10] PN-EN ISO 12213-3:2011 Gaz ziemny. Obliczanie wspótczynnika ściśliwości. Czesść 3: Obliczenia z wykorzystaniem właściwości fizycznych.

[11] Rozporządzenie Ministra Gospodarki z dnia 27 grudnia 2007 r. w sprawie rodzajów przyrządów pomiarowych podlegających prawnej kontroli metrologicznej (Dz. U. z 2008 r. Nr 3, poz. 13 z późn. zm.).

[12] Rozporządzenie Ministra Gospodarki z dnia 28 grudnia 2007 r. w sprawie wymagań, którym powinny odpowiadać gazomierze i przeliczniki do gazomierzy, oraz szczegółowego zakresu sprawdzeń wykonywanych podczas prawnej kontroli metrologicznej tych przyrządów pomiarowych (Dz. U. z 2008 r. Nr 18, poz. 115).

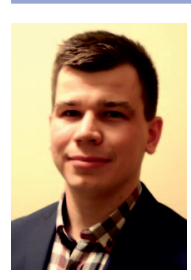

Mgr inż. Maciej ŁACH

Specjalista inżynieryjno-techniczny w Zakładzie Metrologii Przepływów

Instytut Nafty i Gazu - Państwowy Instytut Badawczy ul. Lubicz 25 A

31-503 Kraków

E-mail:maciej.lach@inig.pl 